УДК: 027.7

DOI: $10.20535 / 2020.213251$

Jacek Willecki,

Poznan University of Technology Library,

Poland

\title{
LIBRARY PROJECTS FINANCED FROM NON-UNIVERSITY FUNDS AS A FORM OF IMPLEMENTATION OF THE STRATEGY DEVELOPMENT OF TECHNICAL ACADEMIC LIBRARIES IN POLAND
}

This article analyzes the possibilities of financing from non-university resources of library projects of technical universities in Poland in the financial perspective of the European Union for the years 2014-2020. The library projects serve to implement the strategy of libraries in the most important areas of their development as defined by Polish technical universities in strategic, long-term programme documents. The system supporting the implementation of development strategies and projects in academic libraries consists of four public sector pillars. The institutions at national and regional level, creating this system, offer, through specific area programmes, a high level of support ranging from $80 \%$ to $100 \%$ of eligible costs. Individual programmes, financed from European funds and from the state budget, enable the implementation of project development strategies of repository and digitalization character, promotion and dissemination and increasing innovative teaching and digital competences. The inclusion in the development strategies of Polish scientific libraries of the need to implement projects in the most important areas of their activity should ensure external sources of financing for such projects from the state budget for science, the European Social Fund and the European Regional Development Fund in the next EU financial perspective.

Keywords: areas of library support, library project financing system, science library projects, strategy development of academic libraries.

\section{INTRODUCTION}

Dynamic changes in the area of functioning of higher education institutions in Poland caused by the implementation of the reform called "Constitution for Science" since 2018 should contribute to the introduction of a new, comprehensive approach to scientific research, teaching students and university management. Public higher education institutions will modify the rules of their functioning in order to ensure a higher level of education, combine scientific disciplines and create a federation of higher education institutions (Ministry of Science and Higher Education, n.d.). The changes introduced by the Ministry of Science and Higher Education in this respect are of a comprehensive nature and at the same time confirm the legitimacy of the functioning of academic libraries as organisational units of higher education institutions. The Act of 20 July 2018, the Law on Higher Education and Science defines that a higher education institution operates a library and information system based on a library, and one of its basic tasks is to disseminate and multiply the achievements of science and culture, including by collecting and making 
available library, information and archival collections (Ministry of Science and Higher Education, n.d.a).

\section{Value of academic libraries in the higher education system}

The activity of libraries is also one of the elements of the concept of an efficient state, implemented by the public part of the higher education sector, which is related, among others, to the dissemination of knowledge through scientific libraries (Ernst \& Young, 2010, pp. 20-21). Such libraries significantly support the process of educating students and activities related to the collection and transfer of scientific achievements to the Ministry of Science and Higher Education, as part of the reporting obligation imposed on Polish scientific entities. The need to enlarge and update library resources available in paper and electronic form and the need to ensure the best possible quality of data on the publications of researchers, which are the basis for the evaluation of higher education institutions in Poland, results from strong competition between universities in the domestic education market. Therefore, scientific libraries play a very important but underestimated role in providing access to current scientific knowledge and research data. At the same time, the scope of activity of these libraries is extremely diverse and is not limited only to providing access to the collections and ensuring the functioning of the scientific reporting system. Scientific libraries provide, among others, services in the field of digitization, creation of repositories, digital libraries, reading stands for people with visual, hearing and movement impairments, evaluation of scientific achievements, electronic payments, providing remote access to resources, automation of the process of lending and returning books, training in the field of scientific information for students and academic staff, or organize exhibitions and meetings popularizing science. A wide range of library activities results from the need to provide in the ergonomic space of the scientific library specific remote or stationary services tailored to the needs of users interested in engineering and technical sciences, social sciences or science and natural sciences, with active use of their own website and social media. The legitimacy of the functioning of scientific libraries in the organisational structure of universities is also confirmed by the Conference of Rectors of Polish Academic Schools, which indicates that higher education institutions should provide access to scientific information, library resources in a traditional printed form, digital libraries and specialized electronic scientific databases (Conference of Rectors of Polish Academic Schools, n.d., pp. $80,89,114)$.

\section{Strategic areas of library development in technical universities}

According to the list of universities supervised by the Minister of Science and Higher Education, there are 59 public universities in Poland in 2020, including 18 universities educating in technical sciences (Ministry of Science and Higher Education, n.d.b.). It has been assumed that in a knowledge-based economy the key role in social and economic development is played by access to specialized knowledge offered by technical universities or their specialized organizational units, and this is the group analyzed in this article. On the basis of programme documents defining the directions of development of technical universities in a long-term perspective, the most important areas of functioning of academic 
libraries with a technical profile were identified, which indicate the need to undertake actions significantly influencing their development in the nearest future. The libraries of those academic institutions provide primarily library services related to the provision of printed and electronic collections of science and technology, but they cannot function without taking into account the changing needs of the scientific, economic and social environment in terms of access to information of various forms and scope. Polish technical universities in their development strategies or other equivalent documents have indicated that libraries should, in cooperation with the university or on their own, take various actions to ensure the provision of high quality library services. The catalogue necessary for the implementation of the development strategy of individual scientific libraries includes activities aimed at ensuring full informatization and digitization, increasing the number of available international databases, implementing a unified library and information system (Gawroński, 2011, pp. 19,23,48,72) improving the circulation of scientific information, raising professional qualifications to improve the quality of provided services, modernization and integration of IT systems (AGH University of Science and Technology, 2016, pp. 8, 10), popularization and dissemination of science in society (Silesian University of Technology, 2016, p. 8), development of digital services (Krawczyk, 2011, p. 9), increasing international mobility (Zakrzewska-Bielawska et al., 2019, p. 7), effective knowledge management and providing a place for studying in the library (Wrocław University of Science and Technology, 2016, pp. 21, 23), development of an electronic information management system (Cracow University of Technology, n.d, p. 7), increasing library resources and activities supporting scientific research (Poznan University of Technology, 2010, p. 11), development of IT and ICT infrastructure (Pabian, 2016, p. 4), improvement of processes supporting scientific activity (Rzeszow University of Technology, 2018, pp. 7, 11, 19), informatization aimed at creating an e-university (Bialystok University of Technology, 2013, p. 9), enlarging library collections in the scope of specific directions and specialisations (Kielce University of Technology, 2015, p. 27), introducing a modern information and document management system (Lublin University of Technology, 2013, p. 1), increasing access to electronic book collections (Malik et al., 2019, p. 19), support in the use of information technologies (Koszalin University of Technology, 2015), development of the library infrastructure (University of Bielsko-Biala, 2012, p. 4), implementation of an effective information management system (Brykalski et al., 2011, p. 23) and increasing availability of library resources (Kazimierz Pulaski University of Technology and Humanities, 2016, p. 1). The reference of particular types of developmental activities indicated above by technical universities to the areas of functioning of the libraries indicates that $30 \%$ of these universities notice the need for their digitization and informatization, $17 \%$ see the need to increase library resources, $13 \%$ indicate the need to develop a system of scientific information, $9 \%$ report the need to increase the resources of digital databases and implement an integrated library system, and only $4 \%$ of them identified the need to improve the professional qualifications of library staff and increase their international mobility, carry out activities to promote science, improve information management and provide places to study in the library. After reviewing the content of the websites of scientific libraries with a technical profile, it should be confirmed at the same time that the missions, objectives or scopes of these libraries remain consistent 
with the development strategies of public technical universities, but only $3(17 \%)$ of the 18 libraries of the analyzed group ensured easy accessibility of the content of these missions on their own website. The presented strategic activities, dedicated to libraries in the aspect of the digital transformation to e-science, e-economy and the necessity to improve qualifications throughout life, should be in principle considered necessary and aimed at ensuring continuity of functioning of those organisational units of technical universities.

Libraries in strategic documents of their development must also attempt to anticipate the demand for services that will need to be provided in the near future, which may include, in particular, automated processing of data from source materials and the use of big data sets for scientific and educational purposes (Boyce et al., 2019). Unfortunately, public expenditure on higher education in Poland accounts for only $0.76 \%$ of the gross domestic product (Statistics Poland, 2019, p. 239), which creates significant problems regarding the possibility of financing development strategies and area-based functional strategies of libraries providing access to collections with technical profile.

\section{System supporting the implementation of library projects}

Financial considerations therefore force libraries to actively search for non-university sources of financing for projects aimed at developing new library services, performed by highly qualified librarians who use innovative information and communication technologies based on a secure information infrastructure. Additional, external sources of funding for academic libraries were programmed within the framework of European funds and the state budget for science in the financial perspective 2014-2020, which enabled the implementation of library projects in the above mentioned important areas of their development, identified by universities of technical profile. The system of financing projects from European and national funds in Poland consists of institutions of national and regional level, which, as managing or intermediary units, arrange calls for project proposals. Information on the call for project applications is publicly available and must contain detailed information, inter alia, on the substantive and financial scope of applications and the minimum and maximum amount of support for projects, taking into account the division into individual sources of their financing.

\section{Four pillars of project financing for the implementation of library development strategies}

The first pillar of the public system supporting the implementation of projects of universities and their libraries of technical profile is the Digital Poland Project Centre. The aforementioned national level institution is responsible for implementation of modern IT solutions, acts as an intermediary in transferring funds from the European Regional Development Fund and is supervised by the Minister of Digital Affairs. The institution in discussion conducts activities in Poland covering three strategic areas, ensuring free access to modern IT solutions for such entities as such as public universities and their libraries. The first of these areas includes measures to ensure universal access to high-speed Internet. Such measures are implemented by financing the construction of telecommunications infrastructure, located primarily in sparsely populated areas and far from large 
agglomerations. The second area concerns financing the implementation of e-services, digitisation of printed materials, free access to articles, publications, books, music and films by public administration units and higher education institutions. The third area of support is related to the improvement of digital competences and the use of modern technologies by children, adults, seniors, including teachers and computer programmers (Digital Poland Project Centre, n.d.). Acquiring funding for library projects in the field of digital access to learning resources is possible under the second area of support of the Operational Programme Digital Poland for 2014-2020. The Digital Poland Project Centre through the implementation of sub-measure 2.3.1 of this programme, enables support for projects aimed at wide digital access to scientific resources in the form of open access and popularization of such resources, including, among others, scientific publications, theses, databases, digital repositories, portals and websites, software, research data and results of scientific research, statistics, maps and objects of scientific value, books, magazines and teaching and science promotion materials prepared during the project implementation (Digital Poland Project Centre, n.d.a). The value of eligible expenditure under projects aimed at making science resources available again may not be less than PLN 4 million and may not be greater than EUR 50 million, and the maximum level of co-financing of projects from European funds and the state budget is $100 \%$ of eligible expenditure (Digital Poland Project Centre, n.d.b, p. 5). One of the undertakings co-financed by the Operational Programme Digital Poland for 2014-2020 implemented by a technical university in cooperation with its library is the "Data Bridge" project, which has a budget of 26728876.09 PLN. The aim of the project coordinated by the Gdańsk University of Technology is to create an institutional, consortium repository of open research data for the Gdańsk University of Technology, the University of Gdansk and the Medical University of Gdansk, enabling the deposit and sharing of repository data also by other Polish universities. The project also assumes the implementation of tools for the analysis of large research data sets, supporting the preparation of scientific journals and conferences, and a competence centre supporting activities for open science and open research data. According to data from the Digital Poland Project Center, Gdańsk University of Technology, Cracow University of Technology and Wrocław University of Science and Technology, they have obtained a total of PLN 60037 742.11 for EU funding for 4 projects implemented under sub-measure 2.3.1 of the Operational Programme Digital Poland for 2014-2020 (Digital Poland Project Center, n.d.c).

The second pillar of the public system supporting the implementation of technical library projects of universities is the National Centre for Research and Development, supervised by the Minister of Science and Higher Education. The aforementioned national level institution is responsible, among others, for the implementation of projects concerning increasing the competence of university employees, implementation of software and development of infrastructure supporting university management. The National Centre for Research and Development acts as an intermediary institution in transferring funds from the European Social Fund and the European Regional Development Fund. The support of this institution is characterized by a wide range of fields and themes and is transferred to activities in six strategic areas, ensuring the development of scientific research, development works and innovation. The transfer of European funds for activities in particular 
areas is aimed at strengthening the commercialisation and diffusion of knowledge from science to the economy, ensuring the implementation of projects relating to national defence and security, broadly understood development of scientific and administrative staff and infrastructure supporting these groups, increasing the mobility of scientific staff, increasing competence in the field of entrepreneurship and intellectual property management, and implementing international patent protection for solutions developed by scientific entities (National Centre for Research and Development, n.d.). Acquiring funding for projects enabling the improvement of competences of library staff and infrastructure supporting such activities is possible under the third priority axis "Higher education for the economy and development" of the Operational Programme Knowledge Education Development 20142020. The National Centre for Research and Development through the implementation of measure 3.5 "Comprehensive programmes of higher schools", enables the implementation of projects covering certified training and workshop classes teaching competences, including projects aimed at improving the competences of university employees in the field of innovative teaching and IT skills, the use of professional databases, the use of electronic databases in the educational process, information management and conducting classes in foreign languages. Activities aimed at improving the competences of academic staff in the higher education system also allow for financing projects supporting education infrastructure, concerning the implementation of IT tools for data management, antiplagiarism programmes, creation of scientific repositories and diploma theses and open educational resources (Ministry of Development Funds and Regional Policy, 2020, pp. 193200). The value of eligible expenditure under projects for "Integrated university development programmes" aimed at implementation of comprehensive changes in higher education in the scope of curricula, development of competences of university employees, internship programmes, institutions supporting students, doctoral studies and university management may not be less than PLN 50 thousand and may not be greater than PLN 40 million, and the maximum level of co-financing of such projects from European and state budget funds is 97\% of eligible expenditure (National Centre for Research and Development, 2018, p. 3). One of the undertakings co-financed from the funds of the Operational Programme Knowledge Education Development 2014-2020 implemented by a technical university in cooperation with its library is the project "Integrated University for the future", which has a budget of PLN 14662 375.86. The aim of the project implemented by the Poznan University of Technology is to increase the level and effectiveness of education through the implementation of modules relating to educational programs, increasing the competence of "soft" university employees, improving the university management process and supporting IT tools for data collection. The project also assumes the integration of the Scientific Information System and the Institutional Scientific Repository together with adaptation to the universal central collection environment, which will enable, among others, data segregation, report generation, quick access from one place to full text and abstract scientific data, including open educational resources. According to the data of the National Centre for Research and Development, the Poznań University of Technology, Silesian University of Technology, Lublin University of Technology, Lodz University of Technology, Gdańsk University of Technology have obtained a total of PLN 96259541.13 of EU funding for 5 
projects, under the first path of the call for "Integrated university development programmes", concerning measure 3.5 of the Operational Programme Knowledge Education Development 2014-2020 (National Centre for Research and Development, 2018a).

The third pillar of the public system supporting projects of technical libraries of higher education institutions is the Science Dissemination Activity Programme, which runs until 2019, and then replaced by the Social Responsibility of Science Programme, which is implemented and supervised by the minister responsible for higher education. The Ministry of Science and Higher Education, as a national level institution, is responsible for the implementation of projects within 2 thematic modules aimed at popularising and disseminating science and preserving library resources of significant importance for science or its heritage. The first module called "Popularisation of science and promotion of sport", financed from the state budget for science, supports, among others, the implementation of such activities as popularisation of achievements, works and scientific and development research and undertakings promoting the usefulness of scientific knowledge. The second module called "Support for scientific libraries", also financed from the above mentioned funds, focuses on activities aimed at maintaining library resources which are important for science or its heritage on a national scale, as well as their development and making them available in an electronic version (Ministry of Science and Higher Education, 2019). The value of eligible expenditure on projects whose main objective is to carry out activities popularizing science under the first module may not be less than PLN 20 thousand and may not exceed PLN 1 million, and the maximum level of co-financing for these projects from the state budget is $90 \%$ of eligible expenditure. However, the value of eligible expenditure for projects whose main objective is to maintain library resources and increase digital library resources under the second module may not be less than PLN 20 thousand and may not be greater than PLN 250 thousand, and the maximum level of co-financing for these projects from the state budget is $90 \%$ of eligible expenditure (Ministry of Science and Higher Education, 2019a, pp. 1-2). One of the projects co-financed by the Science Dissemination Activity Programme implemented by a technical university in cooperation with its library is the project "Development of bibliographic records of scientific works published by the employees of the Silesian University of Technology and dissemination in virtual space", which has a budget of PLN 40 200. The aim of the project implemented by the Silesian University of Technology is to make scientific resources available in a digital version. According to the data of the Ministry of Science and Higher Education, the Silesian University of Technology, the Opole University of Technology, the Warsaw University of Technology have obtained a total of PLN 274461 in the last year of the above mentioned programme's operation, from the state budget for science for 3 projects, as part of the call for proposals for libraries (Ministry of Science and Higher Education, 2019b).

The fourth pillar of the public system supporting the implementation of technical library projects of universities is the network of Regional Operational Programmes for 20142020, supervised by 16 Marshal Offices at the request of the Boards of the Polish territorial system. These regional level institutions are responsible, inter alia, for the implementation of measures aimed at digitization and integration of cultural and scientific resources of the public sector, they act as managing authorities of Regional Operational Programmes for 
2014-2020 and provide project support from the European Social Fund and the European Regional Development Fund to beneficiaries. In the case of funds coming from Regional Operational Programmes 2014-2020, obtaining funding by public higher education institutions and their libraries is possible, as a rule, if these entities will act as partners of other organizational units of local government, i.e. project leaders. Such a solution allows for the implementation of joint projects concerning the creation of digital libraries and repositories, preservation and conducting digitalization of cultural and scientific collections and development of ICT systems. The value of eligible expenditure of projects, under the so-called digital priority axes of individual Regional Operational Programmes for 2014-2020, whose aim is to secure, digitalize and disseminate cultural and scientific resources in a digital version, is very diverse in individual voivodeships, and the maximum level of cofinancing of projects from European funds and the state budget is from $80 \%$ to $85 \%$ of eligible expenditure (Willecki, 2018). One of the undertakings co-financed from the funds of the Regional Operational Programmes for 2014-2020, represented by the Regional Operational Programme of the Voivodeship of Silesia 2014-2020 and implemented by the technical university in cooperation with its library, is the project "E-Silesian University of Technology-creation of the platform of electronic public services of the Silesian University of Technology in Gliwice", which has a budget of PLN 5348711 (Regional Operational Programme of the Voivodeship of Silesia 2014-2020, 2017). The aim of the project implemented by the Silesian University of Technology is to implement a public service platform offering such services as e-science and e-repository. The project also assumes the integration of scientific publications with the library system and updating the main library website (Silesian University of Technology, 2018, pp. 13, 99).

\section{CONCLUSIONS}

Programming of the development of science and higher education in the long term should take into account the process of strategic planning, including the analysis of the situation and environment, the definition of the mission and vision, the action plan, the schedule for its implementation and the monitoring system for the tasks to be performed (Chancellery of the Prime Minister, n.d., pp. 19-34). Strategies concerning the mentioned development area implemented at the national, regional and local level must be compatible and complementary. The development strategy of the library must therefore result from the development strategy of its university, which must be coherent with the national higher education development strategy. Particular attention must be paid during its preparation to the clear, precise and comprehensible formulation of a strategic idea for the development of the library that will allow each librarian to define his or her role, commitment and responsibility for its implementation (Brui, 2018). At the same time, the individual activities to be implemented in the framework of the library's strategy must include, among other things, information about those responsible for their implementation, the date of completion of the planned work and the sources of financing for the undertaken actions.

However, the most important issue seems to be to provide funds for the purchase of equipment, software, or to pay for the work performed in the project. This poses an important challenge for libraries, as the budgets they have at their disposal do not, as a rule, take into 
account the level of inflation and have significant limitations when it comes to the need to increase library collections. The strategic development plans of these units can therefore serve both as a preventive measure in case of a need to reduce budget expenditure and to include additional external grants and funds to finance their activities (Saunders, 2015). It should also be noted that the presented possibilities of financing from non-university strategic areas of development of scientific libraries within the framework of projects, offered by public institutions of national and regional level in Poland, are consistent with the areas requiring intervention for these units, identified by technical universities in documents of strategic importance. The developed system of project support, consisting of 4 pillars, makes it possible to obtain funding in a competition system for library projects, which serve to implement strategies for the development of academic libraries of technical profile until the end of 2020. Individual institutions that create a system of financing projects of scientific libraries offer a high level of co-financing from European funds and the state budget, ranging from $80 \%$ to $100 \%$ of eligible costs. This level of co-financing means for the entity applying for support that it is obliged to provide a small own contribution, which will constitute no more than $20 \%$ of the eligible project costs. At the same time, the project guidelines assume a wide range of the required budget amount, which is between the minimum value of PLN 20 thousand and the maximum value of EUR 50 million.

Therefore, scientific libraries in Poland have the opportunity to implement their development strategy, even if there are insufficient funds provided in the budgets of technical universities for this purpose. Operational Programme Digital Poland for 20142020, Operational Programme Knowledge Education Development 2014-2020, Social Responsibility of Science Programme and 16 Regional Operational Programmes for 20142020 offer a wide spectrum of opportunities to obtain funding for the implementation of library development strategies through projects concerning the creation of repositories, platforms and digital libraries, preservation, digitisation and making available of scientific and cultural resources, dissemination of knowledge about library resources and scientific achievements, promotion of open access, raising the competence of library staff in terms of teaching and IT skills, knowledge management and use of professional databases. The scope of support for the above mentioned operational programmes indicates the possibility of implementation through projects, development strategies of repository and digitalization character, promotion and dissemination and increasing innovative teaching and digital competences or enabling their joint implementation in the form of functional strategies of one library. The scale and type of such projects should correspond to the experience of libraries in the implementation of projects, which, due to the amount of the budget, can be divided into small projects with eligible costs up to PLN 1 million, medium-sized projects with eligible costs up to PLN 4 million and large projects with eligible costs exceeding PLN 4 million (Willecki, 2016).

Projects implemented by scientific libraries are therefore a form of implementation of a strategy for the development of these units with a specific source of funding, which requires librarians to be very well prepared in terms of content and knowledge of project guidelines at the stage of project preparation, implementation, financial settlement, as well as in the period of its sustainability after project completion. It should also be emphasized that 13 out 
of 18 public scientific libraries with a technical profile, i.e. $72 \%$ of the analyzed group, publish information on their websites about the total number of 47 realized or completed library projects. The experience gained by the library staff during the coordination of library projects will have a significant impact on increasing the effectiveness of obtaining funds for further projects of this type, and will also allow to minimize the number of errors in the implementation of new projects. Therefore, it seems justified to include in development strategies of all Polish scientific libraries, and not only the libraries of technical universities, the need to implement projects in the most important areas of their activities, which will allow, as a rule, to provide external sources of financing for such undertakings from the state budget for science, the European Social Fund and the European Regional Development Fund in the next financial perspective of the European Union for the years 2021-2027.

\section{REFERENCES}

AGH University of Science and Technology (2016). Development strategy of the Stanisław Staszic AGH University of Science and Technology in Kraków. Retrieved from https://www.agh.edu.pl/uczelnia/dokumenty/misja-statut-strategia/strategiarozwoju-agh/ (in Polish).

Bialystok University of Technology (2013). Development strategy of the Bialystok University of Technology in the 14th term of office 2012-2016 with a perspective to 2020 . Retrieved from http://www.bip.pb.edu.pl/index.php?event=informacja\&id=8164 (in Polish).

Boyce G., Greenwood A., Haworth A., Hodgson J., Jones C., Marsh G., ...Sadler R. (2019). Visions of value: Leading the development of a view of the University Library in the 21 st century. In E., Blakesley (Ed.), The Journal of Academic Librarianship 45, p. 6. https://doi.org/10.1016/j.acalib.2019.102046

Brui O. (2018). Implementation of strategic management based on the balanced scorecard in a university library. In S., O'Connor (Ed.), Library Management 39 (8/9). p. 534. https://doi.org/10.1108/LM-09-2017-0086

Brykalski A., Dawidowski J. B., Baranowska J., Czekiel-Świtalska E., Malkowski A., Rusielik R., ... Wasylik H. (2011). Development Strategy of the West Pomeranian University of Technology in Szczecin for 2011-2020. Retrieved February 20, 2020 from https://www.zut.edu.pl/uczelnia/strategia-uczelni.html (in Polish).

Conference of Rectors of Polish Academic Schools (n.d.). Strategy for the development of higher education: 2010-2020 - project of the academic community. Retrieved February 21, 2020 from https://www.frp.org.pl/pl/projekty-zakonczone/454strategia-rozwoju-szkolnictwa-wyzszego-2010-2020-projekt-srodowiskowy.html (in Polish).

Chancellery of the Prime Minister (n.d.). Strategic planning as a tool to achieve the organization's goals. Retrieved February 27, 2020 from https://dsc.kprm.gov.pl/sites/default/files/pliki/81.pdf (in Polish).

Cracow University of Technology (n.d.). Development Strategy of the Cracow University of Technology. Retrieved February 20, 2020 from http://bip.pk.edu.pl/get.php?id zal=254 (in Polish). 
Ernst \& Young (2010). Strategy for the development of higher education in Poland until 2020-second option. Retrieved February 21, 2020 from http://eregion.wzp.pl/strategie/strategia-rozwoju-szkolnictwa-wyzszego-wpolsce-do-2020-roku-drugi-wariant (in Polish).

Digital Poland Project Centre (n.d.). Tasks and history of the DPPC. Retrieved February 19, 2020 from https://cppc.gov.pl/o-cppc/zadania-i-historia-cppc (in Polish).

Digital Poland Project Centre (n.d.a). Questions and answers 2.3.1 OPDP-Science. Retrieved February 24, 2020 from https://cppc.gov.pl/po-polska-cyfrowa/po-pc-iios/dzialanie-2-3-cyfrowa-dostepnosc-i-uzytecznosc-informacii-sektorapublicznego/pytania-i-odpowiedzi-2-3-1-popc-nauka (in Polish).

Digital Poland Project Centre (n.d.b). Announcement of the call for proposals. Call no. POPC.02.03.01-IP.01-00-011/19. Retrieved February 24, 2020 from https://cppc.gov.pl/po-polska-cyfrowa/po-pc-ii-os/dzialanie-2-3-cyfrowadostepnosc-i-uzytecznosc-informacji-sektora-publicznego/nabor-wnioskow-2-31-nauka-11-nabor/dokumenty-do-pobrania (in Polish).

Digital Poland Project Centre (n.d.c). List of projects implemented from European Funds in Poland in 2014-2020 - as of February 2, 2020. Retrieved February 28, 2020 from https://www.polskacyfrowa.gov.pl/strony/o-programie/projekty/listabeneficjentow/ (in Polish).

Gawroński R. (2011). Development strategy of the Warsaw University of Technology until 2020. Retrieved February 19, 2020 from https://www.bip.pw.edu.pl/Wewnetrzneakty-prawne/Dokumenty-ogolne/Strategia-Rozwoju-Politechniki-Warszawskiejdo-roku-2020 (in Polish).

Kazimierz Pulaski University of Technology and Humanities (2016). Development Strategyof the Kazimierz Pułaski University of Technology and Humanities in Radom for 2017-2021. Retrieved February 20, 2020 from https://www.uniwersytetradom.pl/redirect.php?action=setsubcategory\&subid=44 $\underline{72}$ (in Polish).

Kielce University of Technology (2015). Development strategy of the Kielce University of Technology for 2015-2025. Retrieved February 20, 2020 from http://tu.kielce.pl/wp-

content/uploads/2016/11/Uch S 16215 za\%C5\%82\%C4\%85cznik StrategiaRozwoju-Politechniki-\%C5\%9Awi\%C4\%99tokrzyskiej 2801 2015.pdf (in Polish).

Koszalin University of Technology (2015). Ordinance no. 23/2015 of the Rector of the Koszalin University of Technology of May 11, 2015 regarding the Quality Policy of the Koszalin University of Technology. Retrieved February 20, 2020 from https://www.tu.koszalin.pl/ckeditor assets/attachments/706/zarzadzenie $\mathrm{nr} 23$ 2015.pdf (in Polish).

Krawczyk H. (2011). Basic goals and strategic tasks of the development of the Gdańsk University of Technology. Retrieved February 20, 2020 from https://pg.edu.pl/biuletyn-informacii-publicznej/strategia-rozwoju-uczelni (in Polish). 
Lublin University of Technology (2013). Development strategy of the Lublin University of Technology. Retrieved February 20, 2020 from https://www.pollub.pl/pl/uczelnia/o-politechnice/strategia-rozwoju-pl (in Polish).

Malik K., Adamska M, Będkowski W., Boczar T., Borysiuk Z., Hunek W., ... Polok B. (2019). Development Strategy of the Opole University of Technology until 2030. Retrieved February 20, 2020 from https://www.po.opole.pl/media/akty prawne/2019/strategia uczelni.pdf (in Polish).

Ministry of Development Funds and Regional Policy (2020). Detailed description of the Priority Axes of the Operational Programme Knowledge Education Development 2014-2020, Version 17. Retrieved from https://www.power.gov.pl/strony/oprogramie/dokumenty/szczegolowy-opis-osi-priorytetowych-programuoperacyinego-wiedza-edukacja-rozwoj-2014-2020/ (in Polish).

Ministry of Science and Higher Education (n.d.). Constitution for Science. Retrieved February 21, 2020 from https://konstytucjadlanauki.gov.pl/podsumowanie-zmian (in Polish).

Ministry of Science and Higher Education (n.d.a). Act of 20 July 2018 Law on Higher Education and Science, Journal of Laws 2018 item 1668. Retrieved February 21, 2020 from https://konstytucjadlanauki.gov.pl/pobierz-ustawe (in Polish).

Ministry of Science and Higher Education (n.d.b). List of public higher education institutions supervised by the minister responsible for higher education - public higher education institutions. Retrieved February 20, 2020 from https://www.gov.pl/web/nauka/wykaz-uczelni-publicznych-nadzorowanychprzez-ministra-wlasciwego-ds-szkolnictwa-wyzszego-publiczne-uczelnieakademickie (in Polish).

Ministry of Science and Higher Education (2019). Announcement of the Minister of Science and Higher Education of 3 July 2019 on the establishment of the Social Responsibility of Science Programme and call for proposals. Retrieved from http://www.bip.nauka.gov.pl/inne2/komunikat-ministra-nauki-i-szkolnictwawyzszego-z-dnia-3-lipca-2019-r-o-ustanowieniu-programu-spolecznaodpowiedzialnosc-nauki-i-naborze-wnioskow.html (in Polish).

Ministry of Science and Higher Education (2019a). Guidelines for beneficiaries of the Social Responsibility of Science Programme. Retrieved February 25, 2020 from https://www.gov.pl/web/nauka/spoleczna-odpowiedzialnosc-nauki (in Polish).

Ministry of Science and Higher Education (2019b). List of entities and tasks in the field of Science Dissemination Activities-application type: libraries, that were qualified for funding from the Minister of Science and Higher Education in 2019. Retrieved February 28, 2020 from https://www.gov.pl/web/nauka/wykaz-jednostek-orazzadan-z-zakresu-dzialalnosci-upowszechniajacej-nauke-ktore-zostalyzakwalifikowane-do-finansowania-ze-srodkow-ministra-nauki-i-szkolnictwawyzszego-w-2019-r (in Polish).

National Centre for Research and Development (n.d.). About the Center. Retrieved February 19, 2020 from https://www.ncbr.gov.pl/o-centrum/ (in Polish). 
National Centre for Research and Development (2018). Announcement of the call for proposals no. POWR.03.05.00-IP.08-00-PZ3/18 for Integrated School Programmes-Path no. 3. Retrieved February 25, 2020 from https://www.ncbr.gov.pl/index.php?id=20127\&L=478 (in Polish).

National Centre for Research and Development (2018a). Announcement of the call for proposals no. POWR.03.05.00-IP.08-00-PZ1/17 for Integrated School Programmes-Path no. 1. Retrieved February 28, 2020 from https://www.ncbr.gov.pl/o-centrum/aktualnosci/szczegolyaktualnosci/news/informacja-o-wynikach-oceny-formalno-merytorycznej-wkonkursie-nr-powr030500-ip08-00-pz117-392/ (in Polish).

Pabian A. (2016). Development strategy of the Czestochowa University of Technology in 2016-2020. Retrieved from http://www.bip.pcz.pl/119,strategia-rozwoju (in Polish).

Poznan University of Technology (2010). Strategy for the centenary of the university. Development strategy of the Poznan University of Technology until 2020. Retrieved from https://intranet.put.poznan.pl/department/ro/2010/12/21/3894 (in Polish).

Regional Operational Programme of the Voivodeship of Silesia 2014-2020 (2017). Projects selected for co-financing under the call from Measure 2.1 Support for the development of digital public services. Retrieved February 28, 2020 from https://rpo.slaskie.pl/czytaj/projekty wybrane do dofinansowania 21261020 17 (in Polish).

Rzeszow University of Technology (2018). Strategy of the Ignacy Łukasiewicz Rzeszow University of Technology until 2020. Updated for 2018-2020. Retrieved from https://bip.prz.edu.pl/akty-prawne/uchwaly-senatu/2018/27092018 (in Polish).

Saunders L. (2015). Academic Libraries' Strategic Plans: Top Trends and UnderRecognized Areas. In E., Blakesley (Ed.), The Journal of Academic Librarianship 41, pp. 289-290. http://dx.doi.org/10.1016/i.acalib.2015.03.011

Silesian University of Technology (2016). Development strategy of the Silesian University of Technology for 2016-2020. Retrieved February 20, 2020 from https://bip.polsl.pl/Dokumenty nowe/Strategia rozwoju PS na lata 2016202 0.pdf (in Polish).

Silesian University of Technology (2018). E-Silesian University of Technology-creation of the platform of electronic public services of the Silesian University of Technology in Gliwice. Retrieved February 28, 2020 from https://administracja.polsl.pl/zamowienia/Lists/Informacje/DispForm.aspx?ID=36 (in Polish).

Statistics Poland (2019). Higher education institutions and their finances in 2018. Retrieved from https://stat.gov.pl/obszary-tematyczne/edukacja/edukacja/szkoly-wyzsze-iich-finanse-w-2018-roku,2,15.html

University of Bielsko-Biala (2012). Development strategy for 2012-2020. Retrieved from https://ath.bip.gov.pl/strategia-uczelni/strategia-rozwoju-uczelni.html (in Polish). 
Willecki J. (2016). Developmental projects of university libraries providing access to scientific e-resources financed from national and EU funds. In T., Halski (Ed.), Medical Science Pulse. 10 (1), pp. 32-34. doi:10.5604/2081-2021.1199296

Willecki J. (2018). The development of digital cultural resources financed from the European funds in the framework of projects implemented by libraries and other entities in the culture sector. In K., Jazdon (Ed.). The scientific library: is it still scientific. P. 271-274. Retrieved February 25, 2020 from https://repozytorium.amu.edu.pl/handle/10593/24324 (in Polish).

Wrocław University of Science and Technology (2016). Development Strategy of the Wrocław University of Technology 2016-2020. Retrieved February 20, 2020 from https://pwr.edu.pl/uczelnia/informacje-ogolne/historia-i-rozwoj/strategia (in Polish).

Zakrzewska-Bielawska A., Langer A., Szynkowska M. I., Kubiak T., Hausman S., Piotrowska, D., ... Szymaszkiewicz M. (2019). Development strategy of the Lodz University of Technology for 2020-2025. Retrieved from https://politechnikalodzka.ssdip.bip.gov.pl/strategia-rozwoju-politechnikilodzkiej/strategia-uczelni.html (in Polish). 
Яцек Вілецький,

Бібліотека технологічного університету в Познані, Польща

\section{Бібліотечні проєкти, що фінансуються з позауніверситетських фондів як форма реалізації стратегії розвитку академічних бібліотек у Польщі}

у цій статmі проаналізовано можливості фрінансування позауніверситетських бібліотечних проєктів технічних університетів Польщі у фрінансовій перспективі Європейського Союзу на 2014-2020 роки. Бібліотечні проєкти служать реалізації бібліотечних стратегій у найважливіших сфрерах їх розвитку, визначених польськими технічними університетами у стратегічних, довгострокових програмних документах. Система, що підтримує реалізацію стратегій та проєктів розвитку в академічних бібліотеках, складається 3 чотирьох стовпів державного сектору. Інституції національного та регіонального рівня, які складають цю систему, пропонують за допомогою конкретних програм, що стосуються місцевості, високий рівень підтримки, що становить від 80\% до 100\% прийнятних витрат. Окремі програми, що фрінансуються з європейських фондів та з державного бюджету, дозволяють реалізувати стратегії розвитку проєктів сховища та оцифрування, просування та розповсюдження, а також підвищення інноваційних дидактичних та цифрових компетенцій. Враховуючи необхідність реалізації проєктів у найважливіших сфрерах їх діяльності у стратегіях розвитку польських наукових бібліотек, слід забезпечити зовнішні джерела фрінансування таких проєктів з державного бюджету на науку, європейський соціальний фонд та Європейський фонд регіонального розвитку у наступній фінансовій перспективі Європейського Союзу.

Ключові слова: проєкти наукових бібліотек, система фрінансування бібліотечних проєктів, стратегічний розвиток університетських бібліотек, сфери бібліотечного забезпечення. 